\title{
Una diatriba manuscrita inédita contra Política de Dios de Quevedo*
}

\author{
An unknown handwritten invective against \\ Quevedo's Política de Dios
}

\author{
María José Alonso Veloso \\ Universidad de Santiago de Compostela \\ mariajose.alonso@usc.es \\ ORCID iD: https://orcid.org/0000-0002-9666-5626
}

RESUMEN: Este artículo pretende informar de la existencia de una invectiva inédita contra Política de Dios de Quevedo. Se copia en un manuscrito fechado en octubre de 1626 y dirigido a Antonio de Sotomayor, confesor de Felipe IV y consejero real. Quevedo pudo conocer la diatriba y aludir a ella en el prólogo de su edición autorizada de Política de Dios. La invectiva destaca en el contexto de la polémica en torno a esta obra por su extensión y su sistemática impugnación, por destinatario y alcance político: sitúa a Quevedo en el "bando contrario del privado" (Olivares) y achaca a "otra era", la de Felipe III y Lerma, la corrupción denunciada por el escritor. Su texto permite adivinar las maniobras de enemigos del escritor, alentando en la sombra, ya en 1626, su enfrentamiento con el valido, que será definitivo a partir de 1630.

Palabras clave: Francisco de Quevedo, Política de Dios, 1626, polémica, Respuesta al libro intitulado Política de Dios, manuscrito inédito, Antonio de Sotomayor.

ABSTRACT: This article aims to provide information on the existence of an unknown invective against Quevedo's Política de Dios. It was copied in a manuscript dated October 1626 and directed to Antonio de Sotomayor, Philip the Fourth's confes-

\footnotetext{
* Este artículo es resultado de los proyectos de investigación "Edición crítica y anotada de la obra en prosa de Quevedo, IX" (MINECO, Excelencia 2015, FFI2015-64389-P; AEI/FEDER, UE) y "Edición crítica y anotada de la poesía completa de Quevedo, 1: las silvas" (PGC2018093413-B-I00; AEI/FEDER, UE), del Programa Estatal de Generación del Conocimiento, del Ministerio de Ciencia, Innovación y Universidades. Ha contado también con financiación del Programa de Consolidación y Estructuración de Unidades de Investigación Competitivas de la Xunta de Galicia para el año 2018, "Grupo GI-1373, Edición crítica y anotada de las obras completas de Quevedo (EDIQUE)" (ED431B 2018/11).
} 
sor and royal adviser. Quevedo could get to know the invective and refer to it in the preface of his authorized edition of Politica de Dios. The censure stands out among the attacks related to the controversy about this treatise, due to its extension and systematic objections, its addressee and political scope: the text puts Quevedo on the "opposite side of the chief minister" (Olivares) and blames Philip the Third's monarchy, "another era", for the corruption denounced by the writer. The invective allows us to guess the intrigues of Quevedo's enemies, hidden in the shadows and encouraging, in 1626, his confrontation with the royal favourite, which became definitive from 1630 onwards.

Keywords: Francisco de Quevedo, Política de Dios, 1626, controversy, Respuesta al libro intitulado Política de Dios, unknown manuscript, Antonio de Sotomayor.

El 30 de octubre de 1626, en Madrid, se escribe y dedica a fray Antonio de Sotomayor, entonces miembro del Consejo de Estado de Felipe IV "y su confesor", una grave diatriba contra uno de los textos más difundidos y polémicos de Francisco de Quevedo: Política de Dios, "la obra seria contra la que se volverán con más frecuencia sus enemigos y detractores" (Jauralde, 1999: 498). La Respuesta al libro intitulado Política de Dios, gobierno de Cristo, tiranía de Satanás, inédita y copiada sin nombre de autor, se conserva manuscrita en un códice hoy custodiado en la biblioteca de la Universidad de Pensilvania. Concebida como una completa impugnación del tratado quevediano, publicado en Zaragoza a comienzos del mismo año, posee un notable interés: su fecha temprana, su contenido político, la densidad y amplitud de su argumentación, y sus posibles destinatarios directos (el confesor real, el privado del monarca y el propio rey) la convierten en pieza fundamental de la polémica en torno a la obra.

No es posible conocer con exactitud los efectos que pudo haber provocado en ese ámbito cortesano tan restringido como selecto en el que se habría difundido, pero su propósito resulta evidente: predisponer a los máximos responsables del gobierno contra Quevedo (en el "bando contrario del privado"), y afianzar la posición de los más directos consejeros de Felipe IV, Olivares y Sotomayor. Esta dimensión política de la diatriba resulta sorprendente, como lo es su defensa de la figura del valido: provee un análisis detenido y una completa refutación de la doctrina política de la obra, dibujando en perspectiva el propio contexto cortesano del rey y sus ministros, para evidenciar las diferencias respecto al anterior gobierno, de Felipe III y el duque de Lerma. Al tiempo, denuncia la pretensión de Quevedo de usurpar funciones propias de los consejeros y hasta del confesor real, en lo que podría interpretarse como un intento de hacer tambalear su posición en la Corte de Felipe IV, precisamente después de haber participado en la comitiva real en la visita a Andalucía de 1624 (Jauralde, 1999: 476-482; y López Ruiz, 2008: 232-235) y las jornadas de Aragón, Valencia y Cataluña, en enero de 1626 (Jauralde, 1999: 503-509). La 
insistencia en otra "era", en la que Quevedo estuvo implicado en asuntos turbios como secretario del Duque de Osuna, parece encaminada a empañar sus méritos y negarle el favor real. Esta censura, por tanto, ofrece una nueva perspectiva de la polémica sobre Política de Dios, y contribuye a redefinir la posición de Quevedo en el campo político-literario en torno a 1626, en relación con la corte anterior, la de Felipe III, y la de su sucesor, Felipe IV, auxiliado por el todopoderoso valido Olivares. Tal propósito político no es tan diáfano en otros textos de la polémica, más preocupados por la interpretación inadecuada de los textos sagrados a cargo de un profano en la materia.

Resulta plausible que esta diatriba antiquevediana, la más sistemática y profunda entre las conocidas (las redactadas por el Padre Pineda y, a su zaga, Morovelli de Puebla, Jáuregui o Pacheco de Narváez), hubiese influido en la decisión de Quevedo de redactar una versión "autorizada" de Política de Dios, impresa en Madrid al final de 1626, en la que eliminó el último elemento del título trimembre (tiranía de Satanás), añadió capítulos y modificó la redacción en incontables pasajes ${ }^{1}$. Adicionalmente, su texto inédito anima a formular la hipótesis de que Quevedo aludiese a esta impugnación cuando mencionaba una "respuesta que anda de mano", en el prólogo de la edición autorizada de Política de Dios, y no a la censura del padre Pineda como hasta la fecha se había supuesto.

El presente artículo pretende informar de la existencia del manuscrito inédito y ofrecer una síntesis de sus rasgos materiales, su estructura y contenido, así como de su dimensión ideológica. El análisis de la invectiva está precedido de una breve contextualización inicial sobre la propia polémica y sus hitos más destacados; a continuación, se ofrece una descripción del códice y de los rasgos que permiten afirmar que la Respuesta se basa en la versión temprana de Política de Dios, tal vez en las ediciones zaragozanas, antes de abordar su contenido, cuya eficacia argumentativa se refuerza con múltiples referencias eruditas bíblicas, de la patrística y la historiografía clásica. La extensión de la diatriba me impide transcribir en su integridad el texto, que citaré solo a través de breves fragmentos; en breve publicaré una edición anotada de la obra anónima con un estudio más exhaustivo, actualmente en prensa.

\footnotetext{
${ }^{1}$ Crosby (1975: 6) detalló los cambios introducidos en la "authorized version". Sobre las circunstancias de la redacción y la trayectoria de Quevedo entre 1619 y 1627, véase Jauralde (1999: 397-539). Remito ahora a Alonso Veloso (2020b), a propósito del impacto notable que esta nueva invectiva ejerció en la redacción definitiva de Política de Dios: el cotejo exhaustivo de la Respuesta con la edición zaragozana y la madrileña demuestra que la adición de capítulos y las modificaciones más importantes introducidas por Quevedo en el texto del tratado son consecuencia directa de la diatriba.
} 


\section{LA POLÉMICA SOBRE POLÍTICA DE DIOS}

El año 1626 marca un punto de inflexión en la trayectoria de Quevedo. A partir de esta fecha se suceden las más importantes invectivas contra el escritor y su obra, en coincidencia con la notable divulgación impresa de sus textos más controvertidos: Política de Dios, con nueve ediciones en un solo año (Crosby, 1975: 47), el Buscón o los Sueños, entre otras (Rey, 2014: 54)². La primera de las obras mencionadas protagoniza las principales impugnaciones desde el propio año de su publicación hasta $1640^{3}$. Una diatriba del padre Juan de Pineda ${ }^{4}$, presumiblemente manuscrita y hoy perdida, inaugura la llamada "polémica sobre Política de Dios" (Ettinghausen, 2010 y 2013; y Cacho, 2010: 897-899). Aunque su censura no parece haber llegado a la imprenta, tuvo gran influencia en los índices inquisitoriales sucesivos. Su texto se conoce hoy solo indirectamente, a través de una réplica quevediana, que cita fragmentos del mismo, seguidos por sus justificaciones ${ }^{5}$. Quevedo hubo de sentirse intimidado por el prestigio de Pineda, colaborador del Santo Oficio y "el más importante censor del siglo y quizá de toda la historia de la censura inquisitorial"6, y trató de defenderse, culpando al impresor zaragozano de Política de Dios por haberse basado en un texto corrupto: la edición de Duport contenía más de doscientos errores, concentrados sobre todo en tres capítulos (Ettinghausen, 1969: 324). El escritor intentó contrarrestar el ataque del jesuita con una respuesta Al padre Juan de Pineda, de la Compañía de Jesús, fechada el 8 de agosto de 1626. Después de una rápida introducción, la obra de Quevedo incorpora veintidós apartados integrados por un "texto" (un fragmento de la crítica de Pineda) y una "respuesta" a las objeciones del jesuita. La réplica de Quevedo se habría

\footnotetext{
${ }^{2}$ Los Sueños y el Buscón se encuentran también entre las obras más censuradas; a ellas se añade Gracias y desgracias del ojo del culo, en Venganza de la lengua española (1629), Tribunal de la justa venganza (1635), y Excelencias y desagravios de los nobilísimos ojos de la cara, y zurriago contra el abogado del nefando ojo del culo; véase Alonso Veloso (2017).

${ }^{3}$ Crosby (1975: 6) se refirió al "sharp criticism", que provocó su "revised text". Política de Dios tuvo una gran difusión; remito a Crosby (1975: 5 y 21), quien dudó de posibles traducciones al francés y al italiano previas a las ediciones de Zaragoza; sobre una desconocida versión francesa, Alonso Veloso (2016).

4 Sobre Pineda, Nicolás Antonio, Bibliotheca Hispana Nova (1783: I, 760), y Del Piero (1958: 82).

5 Véanse el prólogo de Política de Dios, "A los dotores sin luz, que muerden y no leen" (edición de Díaz García, 2012, p. 208), Del Piero (1958: 82) y Alonso Veloso (2020a).

6 Son palabras de Márquez (1980: 137), recordadas por Alcalá (1986: 1). Colaboró con la Inquisición en el Index Expurgatorius librorum de Sandoval, y como revisor de librerías para el Novus Index, por encargo de Zapata en 1629, índice que condenó parte de su literatura. Las instrucciones del visitador Juan de Pineda evidencian su poder en la comisión para la visita de libros y librerías; véase Barbazán (1941: 263-264). Gacto (1991: 53) recuerda la repercusión de la crítica de Pineda en el Índice de 1640; remito a Del Piero (1958: 90) y Jauralde (1999: 522).
} 
divulgado como "libelo" o "carta abierta" manuscrita (Del Piero, 1958: 91 y 93), tal vez más ampliamente que la diatriba del jesuita.

Tras el ataque del eminente teólogo Juan de Pineda, el humanista Lorenzo van der Hamen, autor de un preliminar del tratado político quevediano, habría redactado una Apología a la Política de Dios de don Francisco de Quevedo. Dicho texto, hoy desaparecido, se cita con el título señalado en el "Índice de los ingenios de Madrid", de la obra miscelánea Para todos, publicada por Juan Pérez de Montalbán en $1632^{7}$.

Existen indicios de que los ataques del padre Pineda pudieron inspirar las Anotaciones de Morovelli de Puebla contra Política de Dios, pues sus comentarios críticos contienen idénticos argumentos ${ }^{8}$. Este tratado fue criticado con posterioridad en invectivas que censuran también otras obras quevedianas, como un Memorial a la Inquisición contra cuatro textos entre los que se cuenta Política de Dios, datado en torno a 1630 y atribuido a uno de los enemigos conocidos de Quevedo, Pacheco de Narváez. El colofón de esta enconada polémica podría ser Peregrinos discursos y tardes bien empleadas, refutación del mismo Pacheco de Narváez, conservada en un manuscrito de 1640, que no se imprimió, y fue descubierta y editada por Valladares (1997 y 1999) ${ }^{9}$.

\section{DESCRIPCIÓN DEL MANUSCRITO}

Signatura: Ms. Codex 1612.

Fecha: siglo XVII. Datación explícita: "Madrid, 30 de octubre 1626" (al final de la dedicatoria).

Dimensiones: $197 \times 144 \mathrm{~mm} .207 \times 155 \mathrm{~mm}$.

Encuadernación: pergamino del siglo XVII.

Foliación: contemporánea, en tinta, arriba a la derecha: 1 h. $+1 \mathrm{f}$. (portada con escudo) +1 h. + [2] ff. +1 f. (portada con título y citas bíblicas) +134 ff. $+1 \mathrm{~h}$. Errores en la foliación en tinta: el f. 81 se vuelve a numerar como 80 ; los folios 133 y 134 se numeran, por error, como 123 y 124 . Foliación moderna a lápiz, recto superior derecho: [1-141] ff. Algunos reclamos, añadidos tal vez de otra mano.

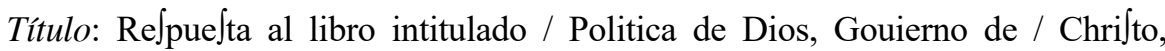
Tirania de Satanas. Una adición posterior también en tinta, tal vez de mano

\footnotetext{
${ }^{7}$ Sigo la edición de Profeti (1981: 563, 225); Álvarez y Baena (1790: 380), y Fernández-Guerra (1852: XC, 240) citan esta Apología, pero continúa en paradero desconocido. Quevedo difundió $L a$ Perinola en 1632 contra el Para todos, generando otra notoria polémica; véase Plata (2006 y 2019).

${ }^{8}$ Astrana (1932: 985-986, n. 2) habló de "plagio" de la censura de Pineda. Véase Jauralde (1999: 522).

${ }^{9}$ Sobre estas impugnaciones, remito a Ettinghausen (2013: 257-259).
} 
de un antiguo propietario del códice, Fernando Moscoso, añade este texto: "que compuso D[on] Fran[cisco] de Quevedo".

Contenido: 1) Dedicatoria a Antonio de Sotomayor (1557-1648), miembro del Consejo de Estado y confesor del rey Felipe IV, a la que se antepone una portada, donde consta la firma manuscrita del antiguo poseedor, "D. Fernando Moscosso", con el título: Re Jpuesta / Al libro intitulado Politica de Dios. / Al Illustrissimo Señor fray Antonio Sotto / Mayor del consejo de estado de Su Magestad / y su confessor. 2) Comentario sobre un apartado introductorio del libro de Quevedo (ff. 1-4v), seguido de veinte "discursos" de extensión irregular, que se inician con el título de los veinte capítulos de la obra de Quevedo Política de Dios, gobierno de Cristo, tiranía de Satanás: 1 (ff. 5-16), 2 (ff. 16v-24v), 3 (ff. 25-34), 4 (ff. 34v-43), 5 (ff. 43v47), 6 (ff. 47v-53v), 7 (ff. 54-60), 8 (ff. 60v-66), 9 (ff. 66v-72v), 10 (ff. 73-78v), 11 (ff. 79-83), 12 (ff. 83v-87), 13 (ff. 87v-96v), 14 (ff. 97-101), 15 (ff. 101v-106v), 16 (ff. 107-112), 17 (ff. 112v-118), 18 (ff. 118v-124v), 19 (ff. $125-129 v$ ) y 20 (ff. 130-134v). El manuscrito contiene abundantes notas marginales, realizadas con la misma caligrafía y tinta que el texto; versan sobre citas clásicas, patrísticas y bíblicas aducidas en la censura. Una de ellas advierte sobre la existencia de un error en una cita bíblica del título de un capítulo del libro de Quevedo: "erro en el original" (f. 101v); esta nota y los abundantes errores y vacilaciones en el vocalismo del texto sugieren que el copista podría ser de origen portugués.

Decoración: dibujo en tinta de un escudo eclesiástico de un obispo (anteportada) ${ }^{10}$; marco ornamental en tinta para $J o b 15,6$, que incluye figuras rotuladas como "Veritas" e "Invidia"; citas de Proverbios e Isaías, en la página del título (portada); algunas manículas de lectores múltiples (ff. 14, 37v-38, 53).

Procedencia: según la información recopilada por la biblioteca, el más antiguo poseedor parece haber sido don Fernando Moscoso (citado en el manuscrito), catedrático de la Universidad de Salamanca, que estuvo activo desde finales del siglo XVII hasta principios del XVIII (su firma figura en la anteportada). Conservado con posterioridad en la biblioteca del Jews' College de Londres (sello y estampado en relieve en los cuatro folios iniciales). También fue propiedad del anticuario de libros y coleccionista Alfonso Cassuto (Lisboa, 1910-1990). Fue vendido en la subasta de Kestenbaum \& Company, como parte de la colección "Alfonso Cassuto" (parte 2, lote 49), en junio de 2011. Hoy se custodia en Filadelfia, University of Pennsylvania, "Rare Book \& Manuscript Library", con signatura UPenn Ms. Codex 1612.

\footnotetext{
${ }^{10} \mathrm{El}$ escudo tiene un capelo, un sombrero de peregrino sujeto con dos cordones, que penden, se entrelazan y terminan en una borla; el número de borlas, aquí 6 a cada lado, simboliza la jerarquía eclesiástica: 3 para obispos (6 por lado), 4 para arzobispos (10) y 5 para cardenales (15).
} 

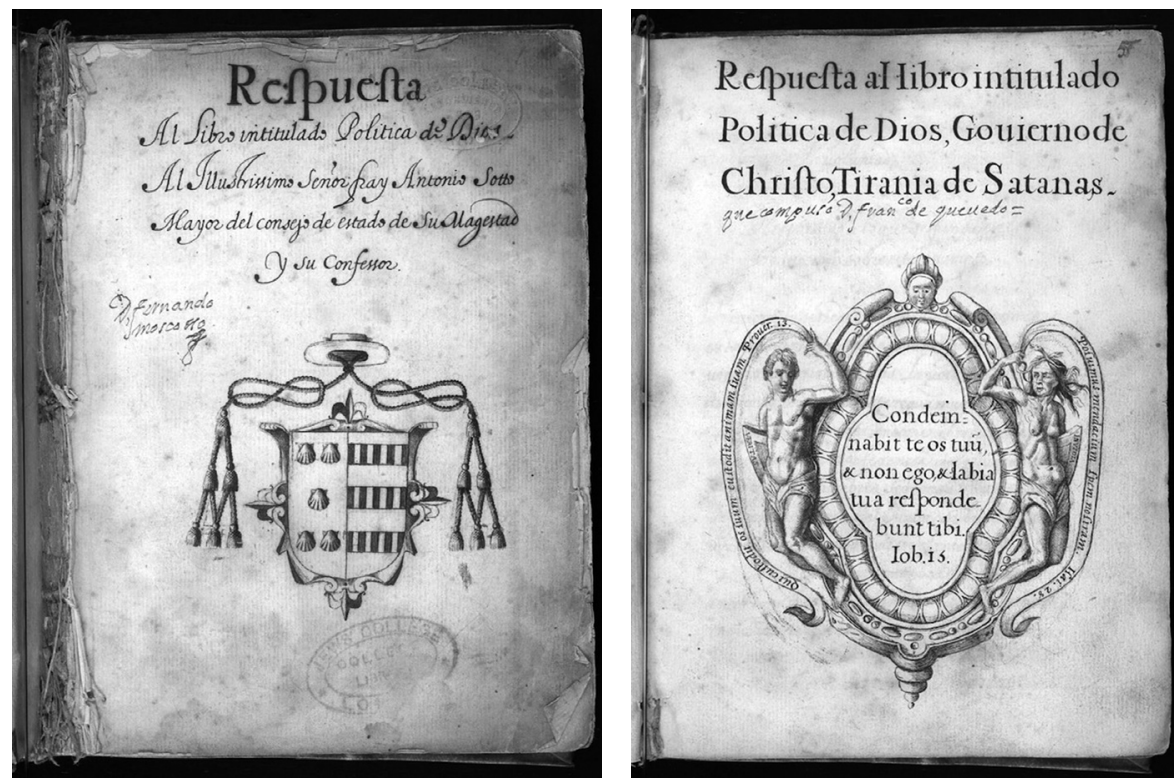

LÁMINAS 1 y 2.--Izquierda: folio que precede a la dedicatoria a Antonio de Sotomayor, con el escudo eclesiástico. Derecha: portada con el título completo y un dibujo a tinta con lemas alusivos a la falsedad de las palabras de Quevedo.

\section{RESPUESTA CONTRA LA VERSIÓN DE LAS EDICIONES TEMPRANAS}

La diatriba inédita, datada explícitamente en octubre de 1626, y por tanto muy próxima a las invectivas de Pineda y Morovelli, se dirige sin lugar a dudas contra el texto de las llamadas "versiones tempranas" ciones zaragozanas publicadas al principio de ese mismo año, pues la dedicatoria del manuscrito justifica la decisión de escribir a Antonio Sotomayor, subrayando el atrevimiento de Quevedo al imprimirla: "el autor llegó a publicarla"12. Me referiré brevemente a los rasgos de estas ediciones "no autorizadas" y a los indicios que corroboran que son las que el autor de la censura tiene delante cuando interviene en la polémica. Pese a que la primera parte de Política de Dios es una obra con una compleja transmisión textual, manuscrita e impresa, y con

11 Para el concepto y los rasgos de la "early version" de Política de Dios, remito a Crosby (1975: 6).

12 Tan intensa actividad editorial coincide con la celebración de la jornada real en Zaragoza y Cataluña (Crosby, 1975: 5 y 26). Sobre esta y la participación de Quevedo, Crosby (1975: 23-24). 
versiones variantes, es posible confirmar que manejó una fuente impresa temprana, como se infiere de la fecha, el título y la disposición de capítulos ${ }^{13}$.

1. Dado que la Respuesta pondera el atrevimiento de Quevedo al publicar su obra, no debió de seguir el texto de los manuscritos "Heredia Spínola" o "Frías".

2. Fecha. El manuscrito está datado en Madrid, el 30 de octubre de 1626, como consta en la dedicatoria a Antonio de Sotomayor. Las fechas de los preliminares de la edición "autorizada" revelan que la Respuesta se redactó poco antes de su publicación, en las prensas madrileñas de la viuda de Alonso Martín: la más tardía, del 11 de noviembre de 1626, consta en la "Suma de la tasa"; 5 de octubre, en la "Fe de erratas"; 1 de octubre, en la "Suma del privilegio"; 16 de septiembre y 27 de agosto, respectivamente, en las aprobaciones legales de González de Ávila y Cristóbal de Torres ${ }^{14}$.

3. El título de la Respuesta al libro intitulado Política de Dios, gobierno de Cristo, tiranía de Satanás apunta explícitamente al de las "versiones tempranas", que en las "autorizadas" se acortó como Política de Dios, gobierno de Cristo ${ }^{15}$.

4. Ordenación y número de capítulos. Las versiones variantes de Política de Dios tienen una numeración y distribución de capítulos no coincidente: entre las fuentes tempranas, el manuscrito "Heredia Spínola" incluye 21, mientras que el manuscrito "Frías" y las impresiones zaragozanas de 1626 contienen 20; las ediciones "autorizadas" por Quevedo añaden nuevos capítulos, un total de tres, situados en la posición 11, 12 y 14, y convierten en capítulo primero el texto introductorio, de modo que alcanzan la cifra total y definitiva de 24 , al tiempo que modifican la disposición del texto. La Respuesta está estructurada en veinte discursos, que impugnan el contenido de otros tantos capítulos de la obra quevediana. Como sus títulos y orden de los distintos apartados coinciden, y además alude a la versión impresa, puede afirmarse que su autor se guía por una de las ediciones zaragozanas. Dicha conclusión se fortalece con otras similitudes; la más significativa es la que atañe al texto precedido por el epígrafe "En el gobierno superior de Dios, sigue al entendimiento la voluntad", concebido a modo de consideración preliminar, que en las ediciones autorizadas pasará a conside-

\footnotetext{
${ }^{13}$ Me baso en los estudios de Crosby (1959 y 1966) y Díaz (2012: 161-184), a propósito de la historia textual de la obra, la filiación y las variantes. Véase también Gendreau (1977, pp. 181196). Remito al análisis de Alonso Veloso (2016), en relación con una desconocida traducción francesa, La politique de Dieu, le gouvernement de Jesus Christ et la tirannie de Satan.

${ }^{14}$ Crosby (1975: 42) estima que la reescritura se produjo "in the summer and fall of 1626".

15 Reacciones contrarias inmediatas debieron de inducir la eliminación del tercer miembro del período. Véanse las consideraciones de Morovelli de Puebla (1932: 986-987) sobre el título, en sus Anotaciones (1626); las de Pacheco de Narváez (1932: 1046), en su Memorial en que denunciaba ante el tribunal de la Inquisición cuatro libros de Quevedo (1630); y las de Juan de Jáuregui (1932: 1074), en El retraído (1635). Sigo en todos los casos la edición de Astrana (1932). Sobre este asunto, remito a Fernández-Guerra (1852: 4) y Alonso Veloso (2015: 124-126).
} 
rarse "capítulo 1". Como señaló Crosby (1966: 358) sobre el manuscrito Frías y las ediciones de Zaragoza, "este capítulo se coloca primero, pero no se denomina capítulo, ni lleva número (el capítulo segundo está numerado como el primero, y los otros siguen sucesivamente)". A este rasgo alude la Respuesta: "Previene la serie de los capítulos el autor con este discurso, que funda sobre seguir en el gobierno superior de Dios la voluntad al entendimiento" (f. 1).

5. Aprobaciones legales. Esta obra se difundió con una dedicatoria a Olivares y varios paratextos; aunque el manuscrito "Heredia Spínola" presenta ciertos rasgos peculiares, dichos textos son compartidos por las versiones primitivas. El contenido de estos preliminares no se comenta en la Respuesta al libro de Quevedo, pero debe llamarse la atención sobre las tres aprobaciones legales (las de Esteban de Peralta y Mendoza, y la licencia de Juan de Salinas), porque la censura reclama castigo también para quienes consintieron se publicase Política de Dios: "Bastaba esta sola proposición para mandar quemar este libro y castigar rigurosamente a los que lo permitieron imprimir" $(10, \text { f. } 74)^{16}$.

6. Contenido y efecto de la censura. Los pasajes denunciados en la Respuesta coinciden exactamente con el texto de la princeps de Zaragoza, y Quevedo parece haberlos reescrito en la autorizada de Madrid, a instancias y "forzado" por su anónimo autor (Alonso Veloso, 2020b).

\section{ESTRUCTURA, CONTENIDO Y ALCANCE DE LA RESPUESTA}

La Respuesta al libro intitulado Política de Dios, gobierno de Cristo, tiranía de Satanás está encabezada por una dedicatoria a fray Antonio de Sotomayor, precedida de una anteportada en la cual consta el título abreviado del tratado quevediano, así como su destinatario. En su parte inferior está dibujado un escudo de armas de un obispado, en el que están dispuestas, en la mitad izquierda de su campo, en vertical y en aspa (2-1-2), cinco veneras. Es posible que la imagen, que no he podido identificar, guarde alguna relación con el autor de la diatriba, quizá un obispo próximo al círculo del monarca y su valido, o bien con el propio Sotomayor. Tal relación sería coherente tanto con la exégesis de las Sagradas Escrituras y la impugnación detallada de la interpretación de Quevedo, como con las citas eruditas aducidas en la argumentación y el conocimiento directo que exhibe sobre el gobierno de la monarquía.

Tras la dedicatoria figura la portada propiamente dicha, con el título completo, debajo del cual se sitúa otro significativo dibujo: en su parte central, una

${ }^{16}$ En mis referencias a la censura sigo siempre la foliación original, en tinta, y no la moderna, en lápiz. Cuando proceda, indicaré, antes del número de folio, el del discurso al que pertenece la cita. En todos los casos he modernizado la ortografía y la puntuación del texto manuscrito. 
cita de Job, 15, 6 lee "Condemnabit te os tuum \& non ego; \& labia tua respondebunt tibi" ('Tu boca te condenará, y no yo; y tus labios testificarán contra ti'); a la izquierda aparece la figura "Veritas", que porta un lema basado en Proverbios 13, 3, "Qui custodit os suum custodit animam suam" ('Quien guarda su boca guarda su alma'); y a la derecha se encuentra la figura "Invidia", cuyo lema se extrae de Isaías, 28, 15, "Posuimus mendacium spem nostram" ('Pusimos nuestra esperanza en la mentira'). Como se apreciará, los lemas citados enfatizan uno de los mensajes esenciales de la Respuesta: la falsedad de las palabras de Quevedo, inducidas por el interés propio y la envidia.

El objetivo censorio de esta Respuesta se deduce desde el propio título de los discursos: "confutando su opinión" (1, f. 5); "En que se impugnan las moralidades con que el autor explica este evangelio" ( 3 , f. 25$)$; "En que se impugna la doctrina deste capítulo y se apuntan los inconvenientes della" (5, f. 43v); "En que se modifica la doctrina del autor y se condena por impía la opinión que sigue acerca de la muerte de san Pedro" (8, f. 60v); "En que se declara el verdadero sentido del evangelio y se muestra cuán errado es el que el autor le da" (10, f. 73); "Impúgnase la doctrina del autor" (11, f. 79); "Apúntanse los inconvenientes de la doctrina que infiere el autor deste evangelio $(12$, f. $83 \mathrm{v})$; "Moralízase este evangelio con contraria doctrina a la del autor" (14, f. 97); "Muéstrase ser falsa y contraria al buen gobierno esta doctrina" (16, f. 107); "En que se muestra ser imposible la prueba de lo que propone el autor" (20, f. 130). Verbos como impugnar o condenar, sustantivos como inconvenientes y adjetivos como impía, errado, contraria, falsa o imposible subrayan tanto el propósito como el contenido del documento, una suerte de memorial solicitando al monarca (a través de su confesor) un castigo.

A lo largo del texto, pero especialmente en los capítulos iniciales, la exposición se apoya en autoridades sagradas y profanas. Sin contar las citas que remiten a pasajes bíblicos y su interpretación, el autor de la Respuesta muestra un apreciable conocimiento de la literatura patrística, pues introduce referencias a san Anselmo, mencionado en ocho ocasiones; san Agustín, Crisóstomo y Caetano (tres veces); san Gregorio y santo Tomás (dos); Cirilo y san Ambrosio (una). Más habituales aún son los autores paganos, entre los que se cuentan historiadores, filósofos y tratadistas políticos: Plutarco, Séneca y Tácito son citados en cuatro ocasiones cada uno; Filón Judío, en dos; Josefo, Valerio Máximo, Platón, Celio, Jenofonte, Bodino, Plinio, Cicerón, Salustio y hasta Alciato, en un solo lugar. A ello se suman menciones de personajes históricos españoles, como el Duque de Barbante, Ramiro de Aragón, don Sancho, Enrique III de Castilla o el rey godo Tulga; y extranjeros, con preferencia por los romanos: Vitelio, Nerón, Calígula, Galba, César, Octavio Augusto, Trajano, Alcibíades o Alejandro Magno, citado este último en tres ocasiones, entre otros. Tal erudición contribuye a reforzar la argumentación, si bien ha de notarse que el grado 
de precisión es variable, y no siempre se introducen citas directas; por otra parte, si en algunos casos se ofrece al margen una referencia completa de la obra y la parte de la misma, en otros no se aporta más dato que el nombre del autor y su obra.

Adicionalmente, resulta llamativo que, ni en el título ni a lo largo de más de un centenar de folios de detenida exposición sobre los veinte capítulos del tratado político de Quevedo, se mencione el nombre del escritor, siempre aludido como "el autor", un rasgo en común con la diatriba tardía Peregrinos discursos, de Pacheco de Narváez.

\section{A Sotomayor: "cortar por lo sano en llagas que suelen comunicar corrupción"}

La dedicatoria inicial desvela el propósito de la Respuesta desde el propio destinatario elegido, el "ilustrísimo señor fray Antonio Sotomayor, del Consejo de Estado de Su Majestad y su confesor". Al apelar a la figura de alguien tan cercano al monarca, Felipe IV, y con un acusado perfil político, se subraya la culpa de quien habría atentado contra la honra del propio rey, por aconsejarlo interesadamente y sin el debido respeto, al tiempo que se acentúa el tono admonitorio y apremiante de las amenazas de castigo. Antonio de Sotomayor (1557-1648), dominico, ocupó diversos puestos en las cortes de Felipe III y Felipe IV; se estima que el momento culminante en que obtuvo mayores atribuciones en la corte fue precisamente en las décadas de los años 20 y 30 (López Arandia, 2014: 62). Con el primer rey, fue confesor del Duque de Lerma y de los infantes; con el segundo, obtuvo diversas prebendas eclesiásticas, ejerció como confesor real, fue consejero de la Inquisición en 1622 y procurador del reino de Galicia en cortes en 1623, comisario general de la Santa Cruzada y presidente de la Junta Grande en 1631, consejero de Estado y de Guerra, así como inquisidor general, en 1632, tras la renuncia de Antonio Zapata y Cisneros, fecha en que el monarca lo nombró abad de Alcalá la Real ${ }^{17}$.

La dedicatoria señala en primer lugar, después del destinatario, el objeto de la impugnación exhaustiva: la obra y la persona de Quevedo, aspirante a "profeta":

Empezando a leer un librillo que acaso llegó a mis manos, cuyo título es Política de Dios [...] Consiste la disposición del libro en moralizar algunos evangelios, y la presumpción de quien lo escribió aspira a profeta.

A continuación, enuncia las líneas medulares de la censura, entre ellas su torcida interpretación de las Escrituras, un rasgo en común con otros textos de la polémica:

\footnotetext{
${ }^{17}$ Sobre Sotomayor y su influencia política, remito a Negredo (2009) y López Arandia (2014)
} 
Por profeta se declara, y aun sube más: evangelista se hace. Por su traza compone evangelios [...] La composición y modo de ellos, suyo es, y como tal muy diferente del sagrado texto, resultando en partes diverso sentido [...] La sustancia de la doctrina es en muchos lugares contra el verdadero sentido de la Iglesia.

Sigue una directa acusación contra las intenciones políticas de Quevedo, uno de los componentes más llamativos de esta censura:

Los documentos políticos, muy diferentes de lo que conviene al buen gobierno, lo que se ve en las contradiciones que sigue, aprobando en un lugar lo que en otro reprueba, para hacer que la razón de estado conforme con su intento, o hallando esta traza más acomodada para emplear su veneno, lo que en estos discursos se verá.

Antes de la despedida, con mención expresa de la fecha y el lugar de escritura (Madrid, 30 de octubre de 1626), aclara que no desea atacar al autor, sino las ideas que expone en su obra, debido al atrevimiento de haberla publicado. Solicita además una intervención rigurosa (¿del propio confesor, del monarca, de sus ministros?) para atajar la "corrupción" de la "doctrina" de Política de Dios antes de que se extienda, alentada por el "aplauso", y provoque "grandes males":

Siempre me pareció materia más digna de sepultarse que de apurar sus yerros, mas, como el autor llegó a publicarla, pareciome necesario responderle. Si la respuesta parece áspera, la materia lo pide. No es mi intento mortificar la persona, mas la doctrina. Necesario es cortar por lo sano en llagas que suelen comunicar corrupción. Ha causado grandes daños en la república cristiana la presumpción de los que profanamente pretendieron explicar las escrituras sagradas, sin fundamento de ciencia; y si el aplauso los desvanece, es principio de grandes males.

Una advertencia preliminar: "Será crimen el disimulo, y la paciencia delicto"

Los contenidos de la invectiva se anuncian ya en el primer comentario, sobre el apartado inicial, que introduce las ediciones zaragozanas y es el primer capítulo de las autorizadas. Acerca de la desatinada combinación de materias sagradas y profanas, advierte que "es ignorancia presumida querer tomar en la boca materias desta calidad para apoyar respetos profanos" (f. 2). Y reflexiona, sobre el "apasionado [...] odio contra los validos" (f. 4) de Quevedo:

No llegaba al medio capítulo el autor cuando [...] se entrega a la pasión de escribir contra privados [...] sin tener paciencia a reprimir el veneno concebido, la mora siquiera de poner un título a materia tan distincta (f. 3). 
La rectitud aborrece en el ministro [...] no halla en ella medio para sus medras, y desea torcido el poder y gracia del privado, de la virtud y verdad a descaminos, en que puedan alcanzarla sus costumbres (f. $3 \mathrm{v}$ ).

Sugiere, antes del final, la necesaria intervención para atajar tales atrevimientos, ante los cuales resultarían culpables la disimulación y la paciencia del monarca:

son saetas de niños semejantes atrevimientos, que no ofenden, entretienen solo y sirven de risa, mas no se les debe permitir usen en ellos de instrumentos sagrados y profanen misterios divinos. Será crimen el disimulo, y la paciencia delicto (f. $4 \mathrm{v}$ )

\section{La materia sagrada "manoseada": "Fulmina el Concilio de Trento escomunión"}

A partir del comentario sobre la introducción, se realiza un análisis completo de Política de Dios, gobierno de Cristo, tiranía de Satanás, estructurado en veinte discursos ${ }^{18}$. Siguiendo el orden de los veinte capítulos de Política de Dios, comienzan siempre con una cita del epígrafe del capítulo correspondiente, a veces con indicación del pasaje bíblico con que se inicia el apartado, seguido del texto "en que se responde", se refuta siempre, la interpretación quevediana de los lugares de la Escritura.

Los discursos se articulan con un doble plano de contenido: el comentario de los textos bíblicos, demostración de los supuestos errores interesados de Quevedo, glosador ingenioso pero carente de conocimientos; y, la parte más novedosa, la directa aplicación de las afirmaciones quevedianas al contexto político contemporáneo, con el propósito de denunciar su espíritu subversivo, en particular su injusta inquina contra el privado y aun contra el confesor real. Ambos planos confluyen en el objetivo de sugerir, o reclamar abiertamente, posibles acciones coercitivas contra el escritor - a quien se sitúa maliciosamente en el bando de los opositores de Olivares-, y desmentir la principal tesis quevediana: la posible imitación de Cristo en un gobierno terrenal.

De acuerdo con las pautas argumentales que he señalado, son constantes las llamadas de atención acerca de la falsificación ("Falso es el fundamento con que prueba el autor su asumpto", 2, f. 21), ignorante o interesada, practicada por Quevedo en lo que atañe a su uso de las Escrituras:

Esta es la doctrina de los santos [...] cualquier que llevare otro camino es falsa y inventada por Satanás, y todos los lugares de Escritura con que

\footnotetext{
${ }^{18}$ El término discurso apunta a un "tratado o escrito que contiene varios pensamientos y reflexiones sobre alguna materia, para persuadir o ponderar algún intento" (Autoridades).
} 
pretendieren autorizarlo serán falsificados y tendrán otro muy diferente sentido (1, f. 16).

Violéntase el entendimiento en que le obliguen a reducir este evangelio a los términos de consulta, siendo materia tan diferente (6, f. 49$)$.

$\mathrm{Y}$, por que no le interpretasen torcidamente, como hace el autor, abatiendo tan misteriosas palabras a tan rastreras materias (17, ff. 112v-113).

El autor de la diatriba acompaña en ciertos lugares su impugnación de una evidente ironía, con la que se subraya la incapacidad exegética de Quevedo:

Colige el autor deste evangelio algunas materias destado, si bien son encontradas al verdadero sentido dél, por más que dice haber buscado con mucha curiosidad y diligencia [...] Dice el autor que inquirió muy cuidadosamente en qué consistió el desacierto de san Pedro. Parece que no le halló en los Santos que exponen el evangelio: consultó consigo el caso y convocó a consejo $(11$, ff. $79-79 v)$.

En otros casos subraya la desautorización que se deriva de que los "seglares", como el propio Quevedo, "manoseen” las Sagradas Escrituras:

Con mucho fundamento prohibieron los sagrados concilios a los seglares que no interpretasen las escrituras divinas; toman dellas lo material, que es el sentido menor, y desautorizan los soberanos misterios de nuestra redención solo con tomarlos en la boca. Más perjudiciales son que ladrones, porque no solo hurtan, mas destruyen: hurtan el sentido que la Iglesia católica y santos dan a la Escritura, y manosean todo lo que toman en la boca; entran sin consideración en el jardín sagrado, no para aprovecharse, mas para pisar y destruir $(7$, f. $54 \mathrm{v})$.

Misterios son soberanos todas sus palabras, no para ser declaradas tan de paso, y mucho menos para probar pensamientos políticos con lo literal dellas. Tienen estos su jurisdición, y límite quien los excede y busca comprobaciones en la Escritura y en la vida de Cristo. Acógese a sagrado, por ser crimen que merece castigo ( 7 , f. 57 ).

Incluso apela explícitamente a la pena merecida por retorcer el sentido de las Escrituras, la excomunión, por supuestas faltas de respeto hacia la materia sagrada que lindan con la blasfemia:

aunque no sin ingenio, se muestra semejanza en lo que es tan distante. Pero en materias políticas ayuda más lo prudente que lo ingenioso, y en las sagradas debe la interpretación ajustarse a las Escrituras en el sentido de la Iglesia y Padres. Y contra los que las tuercen y usan de licencias poéticas con desinios profanos, fulmina el Concilio de Trento escomunión, que debiera ejecutarse rigurosamente por la libertad con que los seglares se atreven, sin fundamento, a interpretar las Escrituras, acomodándolas a sus intentos (18, f. 119). 
Blasfemia sería notar esta acción por el peligro que hay de tentaciones en el desierto. No podía el autor atreverse a tanto [...] Y débese diferente respeto a cosas tan sagradas de que se ha de inferir imitación, y no razones para no haberlas de imitar $(18$, ff. 119-119v).

Aviso político al rey: "sujete muchas veces su gusto [...] a los ministros sabios"

En el plano político, el autor de la diatriba sostiene que Quevedo escribió su tratado arrastrado por una "pasión", su profunda animadversión contra los privados, "blanco a que tira toda la furia" (8, ff. 61v-62): "gran delicto es para el autor ser ministro" (8, f. 61$)$, culparlos "es muy fácil” (2, f. $24 \mathrm{v})$, "Vuelve el autor al ministro [...] ¡Grande cuidado le da este ministro! $(9, \mathrm{f} .66 \mathrm{v})$ :

Materia es sin duda que ha de ser el valido calumniado, y mucho más cuando con mayor primor acudiere al servicio del príncipe; refínase el odio cuando se arma contra dos (4, f. 37).

Mas declarado tiene el autor bastantemente su pasión contra los discípulos; de todo lo que puede infiere calumnias contra ellos [...] por representar los validos, contra quien se armó $(6$, f. $49 v)$.

El autor lo declara a su modo, encaminándolo a su propósito contra los privados, y con tanta presunción como si fuese laureado en la Escritura $(10$, ff. $73-73 v)$.

Redúcese la substancia deste capítulo a cierto género de celo dirigido contra el ministro. Hace el autor razón de estado de que se precie el criado del rey de serlo, no por importar al bien común, sino por imponer nuevos cargos [...] al ministro $(13$, ff. $87 \mathrm{v}-88)$.

El ataque contra la dejación de obligaciones del monarca debió de resultar evidente para los contemporáneos. Tras la muerte de Felipe III, Quevedo pudo dar por concluida "la época de los privados y las privanzas", lo que lo habría animado a difundir "una obra tan atrevida sobre el tema de los valimientos" (Jauralde, 1999: 400).

La Respuesta enumera argumentos que desmienten, uno a uno, los postulados políticos de Quevedo y defienden la necesidad de ministros: "Privados hubo siempre, y es la razón que los haya" (1, f. 13v), "No conviene al rey pelear ni ir personalmente a la guerra" (4, f. 45), "Quien por sí quiere gobernar fía mucho de la fortuna" (6, f. 52), "Tengan los príncipes por razón de estado necesaria a su gobierno remitir los negocios" (6, f. 53v), "No es el príncipe el que ha de asistir a los negocios particulares [...] [gobierna] el príncipe por medio de sus ministros" (9, f. 72$)$, "Acción real es oír a los vasallos, mas no en todo lugar y tiempo" $(12, \mathrm{f} .84 \mathrm{v})$, "las más veces tienen menos amor al príncipe los que tienen mala voluntad al privado" (13, f. 96v). 
Tales consideraciones, desgranadas en sus veinte discursos, conducirán, de manera más acusada hacia el final, a la impugnación de la tesis principal del tratado de Quevedo: la posibilidad de tomar la vida de Cristo como ejemplo válido de gobierno para los príncipes, porque "es muy desigual el gobierno de Dios al de los hombres" (10, f. 73v), "por diferente modo de los hombres gobierna Dios" (11, ff. 82-82v) y, en suma, "no es el gobierno de Cristo el que han de imitar los príncipes" (20, f. 133):

Y constará cuán imposible es probar su asumpto por el camino que pretende, juzgando que solos los documentos que colige de lo literal de la Escritura, entendida a su modo, es de la que Dios usa; siendo tanta la diferencia que de ningún modo se puede hacer consecuencia del gobierno divino al de los hombres [...] Medir las acciones humanas por las divinas y regular el gobierno de la tierra por el del cielo es temeridad a que no se atrevió pensamiento humano (20, ff. 131).

La propia conclusión de la Respuesta adopta la forma de un consejo al príncipe (al rey Felipe IV), instándole a no adecuar sus acciones políticas al gobierno de Cristo:

daré fin a ella con advertir a los príncipes que procuren imitar a Cristo en la pureza de sus vidas; mas no pretendan ajustar las acciones del gobierno a las de Cristo, que, siendo tan diferente gobernar hombres y padecer por ellos, y tan distantes las personas como Dios omnipotente y hombre frágil, sujeto a los accidentes del tiempo, no es posible haya conformidad en las acciones (20, f. 134).

Tales sentencias, al tiempo que desacreditan al consejero Quevedo, fortalecen la posición de los más cercanos colaboradores de Felipe IV. Como sucede en un pasaje en el que se pondera la conveniencia de que el joven e inexperto monarca sujete el "parecer propio" a la madurez, prudencia y sabiduría de sus ministros:

La felicidad en el gobierno destos príncipes, en falta de experiencia, en el amor de las pasiones de la edad debe sin duda referirse a la prudencia de los ministros [...] siempre acierta en ayudarse en el gobierno de la prudencia y vigilancia del ministro sabio y recto [...] Y no solo es prudencia, mas valor en el príncipe sujetar la afición del parecer propio, principalmente en materias que tocan a su gusto o interés, a las razones que con madurez pondera el juicio libre de los ministros sabios (16, ff. 109-110).

Cuando fue coronado rey tras la muerte de su padre, en 1621, Felipe IV contaba solo 16 años, 21 en el momento en que se escribe la censura. Un nuevo argumento para defender la pertinencia de los consejeros con un monarca inexperto, en contra del criterio de Quevedo: "Y sujete muchas veces su gusto y opinión a los prudentes acuerdos de los ministros sabios y experimentados" (16, ff. 111-111v). 
Bajo la impugnación directa de Quevedo y su obra, subyace en la Respuesta la reprobación de las acciones de los responsables del gobierno, validos y ministros, de la época anterior. En lógica consecuencia, y en relación con el destinatario del escrito - que hubo de ser múltiple al menos en la voluntad de su autor, pues habría deseado que volase desde las manos del confesor a las del monarca y su privado-, se insertan múltiples elogios hacia el contexto político del momento y las hazañas de sus gobernantes:

Cuando se levantaron mayores tempestades, cuando se conjuraron con mayor furia los mares contra esta nave, cuando amenazaron mayores peligros, acudió la vigilancia de los pilotos a tan buen tiempo que fue mayor la afrenta de los enemigos que el peligro que se recelaba [...] ¿Qué fortaleza hay que ya agora no pueda resistir a toda la fuerza de los enemigos, estando hasta ahora por el suelo? ¿Cuándo se empleó menos la hacienda real en ocasiones ociosas, en dádivas pródigas? ¿En qué edad estuvo más en su punto la justicia? ¿Cuándo cesó la jurisdición de los cohechos, la costumbre de vender y comprar ya casi introducido por ley? ¿Cuándo se correspondió con mayor cuidado a los beneméritos o se premiaron servicios, distribuyéndose las mercedes sin adulación, sin respetos particulares? Quien no da fe desto debe de dormir [...] Y no faltará quien use de la misma traza para castigar, para ser el castigo proporcionado a la culpa $(9 \text {, ff. } 70-71)^{19}$.

¡Dichosa edad! ¡Dichosa monarquía, que tan largos recibe los favores del cielo, en lo que se defiere a los acuerdos prudentes de ministros justos y sabios! (16, f. 112).

Tal panegírico es concordante con el espíritu del "annus mirabilis" (Elliott (1990: 234-250) de 1625, en que se produjeron grandes victorias para España en Brasil, Breda, Génova, Cádiz y Puerto Rico, una época en que Olivares reivindica los éxitos de su política, no exenta de una gran oposición interna ya entonces. Pese a que en 1626 se acentúan los problemas, tras la convocatoria de cortes en Aragón, Valencia y Cataluña, y el fracaso de la Unión de Armas (Elliott, 1990: 251-283), persiste la idea del contraste con la situación heredada en 1621, a la muerte de Felipe III: "el tesoro exhausto, los ministros corrompidos, ejércitos y armadas víctimas de la incuria y la desmoralización" (Elliot (1990: 245).

${ }^{19}$ Insiste en tal argumentación en el discurso quince: “¿Qué edad se podrá gloriar de haber gozado gobierno más ajustado a la verdad, más conforme a las resoluciones de los tribunales, en que con tanto acuerdo y justicia se tratan las materias? ¿En qué tiempo valieron más los méritos o se pagaron más puntualmente los servicios? ¿Cuándo estuvieron las puertas tan cerradas a todo género de cohecho, así en las materias graves como en las ligeras?" (15, f. 104v). 
Un perfil político de Quevedo: "no se le ha hecho mal trato: en la paz vive que antes"

La Respuesta descalifica en diversos pasajes el libro de Quevedo en relación con su contenido y estilo, sus doctrinas "fantásticas y fundadas en sentidos alegóricos" (18, f. 123v), sus "razones sofísticas con demasía" $(13$, f. $94 \mathrm{v})$, cuyo resultado sería un desorden o un discurso contradictorio inducidos por la malicia y la pasión de sus consejos políticos interesados $(16, \mathrm{f} .108 \mathrm{v}$ y $17, \mathrm{f}$. 116): "No abona la persona lo bien hablado, que lo sabe muy bien hacer el diablo: no pasa de apariencias, suspende y divierte con el deleite" (18, f. 123). El desorden, o las "razones sin orden" de Política de Dios, carecen de "sustancia" y son "significadoras del ánimo del autor" (8, ff. 66).

Pero los discursos apuntan con más frecuencia hacia el perfil político y moral de Quevedo. La Respuesta introduce interesantes juicios sobre su posición en la Corte, "experimentado, mas no arrepentido", con los que podría aludirse a los graves sucesos relacionados con el final del reinado de Felipe III, con los Duques de Lerma y Uceda, así como a su experiencia como secretario del Duque de Osuna, caído en desgracia y causa de uno de sus destierros tras el periplo italiano:

Comienza el autor a declararse contra los privados, y el primer parecer que sigue en esta materia es que los príncipes no los tengan, opinión que ha pocos años sigue, porque, a tenerla antes, pudiera ser causa de su destruición. Experimentado, mas no arrepentido, habla en excesos de privados (1, f. 13).

Y de que lo hagan los príncipes, es buen testigo el autor, pues, hablando tan libre, no siendo profeta ni predicador, no se le ha hecho mal trato: en la paz vive que antes, sin temor de venganza o de castigo $(17, \mathrm{f} .117)$.

Pese a sus errores políticos y a la excesiva libertad de sus palabras - parece argumentarse-, Quevedo gozaría con el nuevo gobierno de una tranquilidad tal vez inmerecida y que debería acabar. Si el escritor se hubiera atrevido a atacar así al privado del anterior monarca — como lo hace con el de Felipe IV, rey reputado de benevolente en la invectiva-, habría sido ya destruido.

El autor desconocido de la diatriba comenta incluso circunstancias del proceso de redacción de la obra, cuyas primeras versiones se remontan al reinado de Felipe III y, por lo tanto, a privados diferentes de los que ejercían como tales en 1626. Aduce una aparente disculpa del escritor, que no habría actualizado sus consideraciones a la vista de la buena marcha del gobierno de Felipe IV, pero esta aclaración desemboca en realidad en una más eficaz condena de la malicia de Quevedo, quien habría pretendido imputar al monarca males propios de "otro tiempo", de la "era" anterior:

En que se ve que se hizo en otro tiempo este libro, aunque se publicó en este, en el cual la experiencia de todos condena las intenciones del autor. 
Porque en ninguno estuvieron tan francas las puertas de palacio, y sin porteros las de los ministros superiores, en quien pudiera el peso grande de los negocios disculpar cualquier retiro (12, f. 84).

Hallo al fin deste capítulo alguna disculpa al autor de lo que escribió, no de haberlo sacado a luz en este tiempo. Ya lo apunté en el capítulo 12: son papeles que se escribieron en otra era [...] en todo el discurso del libro se conoce así, pues no vemos sombra de los delictos que en él arguye [...] Prosiguía lo empezado: viva imitándose a sí, no se canse de copiarse las acciones de un día en otro. Notorio es que ninguno dio ocasión en este gobierno a tales demonstraciones y castigos [...] Prosiga lo empezado, que en otro tiempo vendrían a propósito. Pero tengo por mayor culpa querer infamar el nuestro con imponerle vicios de los pasados, pretendiendo afrentar las virtudes con el azote que se hizo para castigo de vicios $(15$, ff. $105 \mathrm{v}-106)$.

El texto de la censura inédita dibuja un retrato del perfil político de Quevedo: el propio de un "envidioso" $(11$, f. 80$)$, resentido y "ambicioso", que "se considera en mal puesto" por no haber alcanzado aquel al que aspiraba, y que con sus consejos busca desestabilizar el gobierno, induciendo novedades:

los abatidos de la fortuna no quieren que pare su rueda, sino que camine ligeramente. Consiste su comodidad no en la paz de la república, descanso del príncipe, justicia de los vasallos, sino en la revolución de todo. Cierto político de nuestros tiempos dijo ser la guerra la más ocasionada para hacer hombres dichosos [...] No estraño que haya quien desee novedades, si se considera en mal puesto quien las pretenda; sí, pues es fuerza que se arme contra su propia patria, que procure buscar remedios violentos para destruirla a cuenta de quedar mejorado, que mudanzas de gobierno pocas veces causan buenos efectos y, si estas son inducidas por ambiciosos, paran cuando menos en libertades y atrevimientos (3, ff. $33 \mathrm{v}-34)$.

Peligrosa cosa es cerrársele la puerta de sus designios a un ambicioso que arremete como perro rabioso a su propio señor $(4, \mathrm{f} .39)$.

En el primer pasaje, la posible alusión al pensamiento político de Maquiavelo en torno a la guerra impugna la doctrina quevediana, inspirada en el más denostado tratadista de la época. En otro lugar se insinúa que Quevedo formaría parte del "bando contrario del privado", razón contundente para que no gozase del favor del príncipe:

$\mathrm{Y}$ en el gobierno político conviene muchas veces que los favores del príncipe no se empleen en los que son de bando contrario del privado, a los cuales no se ha de dar mucha mano, porque viven de ordinario descontentos y desean desacreditar las acciones del príncipe por la parte que tiene en ellas el privado; y la destruición del reino, por satisfacer y hartar su envidia. Y ningunas mercedes ni favores bastan para contentar los que su mayor disgusto es la vista del privado; y, mientras él permanece, siempre han de vivir descontentos, por más mercedes que les haga el príncipe $(13$, ff. $95 \mathrm{v}-96)$. 
es de admirar en la poca esperanza que puede tener de ser de los que reciban (20, ff. 130v-131).

Quevedo intentaría hacer las veces de consejero, "sin ser rogado" para ejercer tales funciones, indicio cierto de que actuaría movido por interés y malicia:

quien por su autoridad y sin ser rogado se quiere hacer consejero de estado, propio interés le mueve [...] Sábelo disfrazar con apariencias de buen celo, tiene ingenio para aplicar sus razones al fin que pretende, que el demonio no perdió la sabiduría con la gracia; a muchos pudiera engañar, si no hubiera quien quitase el rebozo a su malicia. La más cierta señal para conocer cuál sea consejo verdadero y cuál fingido es reparar si el consejero es rogado o ruega: quien ofrece consejo interesado está en él, y quien le persuade más que interesado malicia incluye [...] Tribunales hay en que se examinan los consejos provechosos y necesarios; los consejeros dellos son escogidos por acuerdo del príncipe, aprobados en las costumbres, no con nota de vicios. Estos dan su consejo en lo que les piden, no en lo que ellos quieren; y todas estas calidades se requieren en quien ha de aconsejar al príncipe $(5$, ff. $39 \mathrm{v}-41)$.

La Respuesta denuncia que Quevedo se retrata en Política de Dios deseando "parecer oráculo", por pronunciar "palabras equívocas" (5, f. 41); con pretensiones de "profeta", a lo Jeremías (10, f. 73v) o a lo Miqueas (19, f. 129); vestido de "ermitaño" para usurpar "el oficio a los predicadores evángelicos" $(8$, ff. $65-65 \mathrm{v})$; "laureado en la Escritura" (10, f. 73v); "religioso y predicador" $(9$, f. $67 \mathrm{v})$; "predicador del rey, confesor y teólogo" (10, f. 78v). Ya hacia el final del texto, la argumentación superpone a las distintas víctimas de la emulación quevediana, "privados, consejeros y ministros", añadiendo al confesor real, a quien el pretendido profeta habría querido relegar, arrogándose más capacidad y méritos para ejercer como tal. El título del capítulo de Política de Dios aludido leía: "Consejeros y allegados de los reyes, confesores y privados".

Hace en el título una recopilación de todos los que le dan cuidado, si no es que, queriendo dar documentos al confesor, le pareció atrevimiento y quiso disimularlo con mezclarle con otros, o bien quiso declararnos a qué príncipe dirige estas sus advertencias: no al de Inglaterra o a otros heréticos o paganos, sino al que, católico y religioso, admite a su consejo y se gobierna en las materias más graves por el celo, virtud y letras de sus confesores. No halla seguro el autor este género de gobierno. Mostró ya su ánimo contra los privados, consejeros y ministros; ármase agora contra el confesor. $\mathrm{Y}$ en todos quiere mostrar incapacidad, y que en sí solo hay partes para cumplir las obligaciones de confesor [...] Y supuesto que él los aconseja, bien se ve que halla en sí todas las calidades que en los otros halla menos [...] ¡Cuán cierta perdición les procura en este documento el que hace lo que no halla lícito en el confesor! Aconseja, doctrina, reprehende, y con todas trazas quiere persuadir. Si no confesor, profeta, que por tal se ha declarado, usurpando el lenguaje a los profetas (19, ff. 125-126). 
No parece ocioso subrayar que la Respuesta se dirige, precisamente, al que entonces era confesor real, Antonio de Sotomayor, a quien se intentaría predisponer contra Quevedo, presentado como un peligro incluso para la posición de los más altos consejeros. Confesores y predicadores reales acumulaban en la época casi más poder político que religioso, lo que explicaría la gravedad de la acusación de osadía y el presumible malestar cortesano que habrían generado las pretensiones quevedianas ${ }^{20}$.

Por oposición al perfil de Quevedo como asesor de monarcas que se postula en Política de Dios, la impugnación retrata a un escritor de cuya literatura ha de inferirse que es "demonio" ( 2 , ff. $17 \mathrm{v}$ y 24$)$ cargado de "ponzoña" (2, f. 24); ladrón de la honra de monarcas y vasallos $(4, \mathrm{f} .43)$, herético e impío $(8, \mathrm{f}$. 61); "verdugo de honras y vidas ajenas" o "mendigo" (9, f. 67v); de "consciencia imunda y torpe" (14, f. 100); "profeta del diablo" (15, f. 105); "inconsiderado", apasionado y malicioso (16, f. 107); de "ánimo sofista" en el uso equívoco de las palabras sagradas $(16$, f. $107 \mathrm{v})$; "ministro del demonio" (16, f. 111); "diablo que se hace teólogo y alega escrituras" (18, f. 121); "falso profeta", pues "habla profeta y obra Satanás" (19, f. 129v):

Celo disfrazado que, por receloso, se acoge a sagrado; que se viste de ermitaño para engañar a Cristo y para persuadir con apariencias de verdad, usurpa el oficio a los predicadores evangélicos, valiéndose para destruir el mundo de las misteriosas acciones de la vida de Cristo (8, ff. 65-65v).

Confúndense las especies: tal vez se imagina entre sueños religioso y predicador el que nunca se ocupó más que en ser verdugo de honras y vidas ajenas; tal vez le parece que es rey que halla tesoros el que siempre vivió mendigo $(9$, f. $67 \mathrm{v})$.

En síntesis, constata que Quevedo no puede aspirar a ser "varón de sangre"; bien al contrario, responde a los rasgos del "hombre de sangres":

hallaremos que es diferente ser varón de sangre o varón de sangres. Hombre de sangre es el noble que cumple su deber, el que honra a todos, y en especial a sus superiores; hombre de sangres, el que se sustenta de las honras ajenas, el que se deleita en desacreditar la nobleza, la virtud, los que gobiernan $(17$, f. $117 \mathrm{v})$.

El retrato contiene también alusiones a los vicios morales, al supuesto contraste entre los consejos que disfraza bajo "capa de bien común" y su propia vida, entre las palabras y las obras:

\footnotetext{
${ }^{20}$ Remito a Negredo del Cerro (2006) sobre los predicadores de Felipe IV y las intrigas palaciegas en las que participaron, en especial Hernando de Salazar, confesor y consejero de Olivares (pp. 117-140).
} 
Reformad primero vuestra vida y censurad entonces las ajenas; mal puede tener celo de los otros quien no tiene piedad de sí (2, f. 24v).

Si son penitentes mortificados, dados a oración, amigos de los pobres, será su espíritu de Dios; mas, si son sensuales, deshonestos, envidiosos, dados a gula y a otros vicios, no los creáis $(9$, f. 70$)$.

Bien representa la figura de profeta, pero es en las palabras, debiendo parecerlo en la vida; que hablar profeta y obrar Satanás es de muy falsos profetas $(19$, f. $129 \mathrm{v})$.

Las recomendaciones de reforma moral apuntan hacia su condenación, por falsedad y envidia, anunciada ya en las citas bíblicas de los dibujos iniciales.

\section{Delitos y amenazas: "ya se imagina preso, afrentado y castigado"}

Del contenido político de la Respuesta se infieren advertencias al monarca y sus ministros para que dejen de consentir atrevimientos contra su honra como los protagonizados por Quevedo y descubran sus verdaderas intenciones:

¡Grande es el atrevimiento de un envidioso! [...] Y hace sus demandas muy fundadas en piedad, siendo todo cautela y malicia. Consideración que el príncipe debe tener para penetrar el ánimo de los que, muchas veces con disfraz del bien común, quieren satisfacer la pasión particular: alegan celo, y encubren malicia $(11$, f. $80 \mathrm{v})$.

Crece más en algunos la ambición en pretender, malicia en acusar, descaramiento en calumniar. Debe así crecer en los príncipes recato en oírlos, dificultad en creer y prudencia en responderles [...] No es piedad dar oídos al desalmado, al que tiene librado su felicidad en desautorizar a todos: crueldad fuera el darle crédito $(12$, f. 86$)$.

La culpabilidad política de Quevedo se subraya en el discurso quince, donde se pondera el "muy nuevo y extraordinario y quizá no visto [...] estilo de escribir de nuestro autor" (f. 101v); se le acusa de insinuar graves delitos en el propio monarca, que desautorizan y disminuyen su honra; y se exige una pena severa, acorde con el crimen:

esta manera de calumniar, amonestar con celo fingido y predicar emienda de delictos solo a fin de dar a entender que los hay y que se crea que algo hubo que diese motivo a tal doctrina, es lo más a que pudo llegar malicia humana [...] Pero el autor no es lo que pretende dar consejos errados, sino a entender que cometen delictos grandes los que gobiernan [...] Contra sí habla en lo que pretende se castiguen otros. Desautorizar las acciones del rey, profanar el celo con que se trata lo que toca a la religión, manchar la pureza con que se procede sin respeto a interés, es la mayor insolencia que ningún atrevido 
puede cometer. Más es que desautorizar la casa: no basta azote, no hay castigo que iguale el crimen que llega a tocar en la honra (15, ff. 102-104v).

En correspondencia con las admoniciones previas, la Respuesta se articula como una amenaza, si bien atenuada por la clemencia que se atribuye al monarca. Tal estrategia conlleva la sugerencia de una necesaria enmienda de Quevedo, cuyas palabras acusan una excesiva libertad, porque la paciencia del príncipe "tiene su término". Paradigmático resulta el discurso noveno, al que pertenece el primer ejemplo:

No taparles la boca, efecto es también de buen gobierno [...] Siempre fue objecto de príncipes, y algunas veces es permisión divina, que falte quien cierre la boca a los desalmados, para que ellos sean verdugos de sí mismos. Mucho desea el autor al príncipe despierto [...] En esta ocasión solamente deseo al príncipe durmiendo, porque la paciencia tiene su término [...] El mucho ladrar no solo despierta, mas provoca [...] Mucho temo al autor no aquietarse: vuelve a repetir lo mismo y a alzar más la voz [...] ¡Peligrosa cosa es un espíritu presumido, principalmente cuando es fundado sobre vanidad de acciones poéticas! Quiere formar misterios; y de palabras vanas, profecías. ¡A quién no admirara esta libertad de hablar! $(9$, ff. $68 \mathrm{v}-69 \mathrm{v})$.

Estos son con propiedad ladrones dignos de todo castigo, que viven de prestado, debiendo la vida a la satisfación de sus delictos. Si se la permite la disimulación y modestia del tiempo, la generosidad de los que gobiernan, mucho debe agradecer y poco especular la materia de su asumpto $(17, \mathrm{f} .118)$.

Pero lo cierto es que la conveniencia de un castigo ejemplar se propone como única vía para evitar la deshonra del príncipe o los desórdenes públicos. Como se subraya, "usar de la clemencia en casos de malicia es aprobar el crimen y dar confianza a atrevidos (2, f. 22v)", y "traidores conocidos, demonios obstinados son incapaces de enmienda, y es indigna en ellos la clemencia" (2, f. 23): "No permitan los príncipes que se les atrevan" (3, f. 28). Como sentencia la invectiva, "se hace digno de cualquier castigo el que en cualquier materia se atreve al príncipe; y él queda disculpado si castigare sus libertades, porque es en este caso virtud, no vicio, la venganza" (17, ff. 117-117v).

Cosa es antigua la murmuración contra los príncipes, mas guarda también su límite la disimulación [...] mas atrevimientos ofenden mucho al brío y valor real. No pretendo exasperar los príncipes, sino advertir a los atrevidos que se vayan a la mano, que la paciencia refrenada castiga más rigurosamente que la cólera $(3$, ff. $29-29 v)$.

Si hubiese particular castigo para unos locuaces que se precian de embelecar al pueblo por el aplauso con que celebra sus dichos, teniendo por oficio agradar a costa de la honra ajena, escusaríanse en la república muchas desórdenes. Por esta causa juzgo yo que los lacedemonios desterraron los poetas; vicio es que tienen muchos de ellos $(4$, f. $37 \mathrm{v})$. 
El "estilo más que impío" de Quevedo exigiría no solo que el libro fuese pasto de las llamas, sino el más riguroso castigo para quienes habían consentido su difusión: "Este es el tercer lugar en que el autor habla por este estilo más que impío [...] Bastaba esta sola proposición para mandar quemar este libro y castigar rigurosamente a los que lo permitieron imprimir" $(10$, f. $73 \mathrm{v})$.

En una amenaza velada, la Respuesta atribuye al propio Quevedo, al final de su libro, una confesión de su temor y sus quejas ante el castigo que merece y le será infligido: "Ya se imagina preso, afrentado y castigado. ¡Oh, cuánto le ha de pesar de ser en esta ocasión profeta, que suele la malicia adivinar sus castigos!" (20, f. 128v).

La breve selección de pasajes de la Respuesta evidencia la descalificación global de la persona y la obra de Quevedo. Al tiempo que propone su retrato político, literario y moral, traza un encomio desmedido del monarca y sus ministros, con el que se busca hiperbolizar la distancia entre la corte de Felipe IV y la corrupción denunciada por Quevedo, propia de "otra era", la del gobierno de Felipe III y su privado Lerma.

\section{CONCLUSIONES}

La crítica ha considerado que las afirmaciones de Quevedo sobre los ataques divulgados contra su Política de Dios, insertas en el prólogo de su edición "autorizada", aludían a la diatriba de Juan de Pineda. "A esto se ha seguido una respuesta que anda de mano, a mi libro, sin título de autor [...] hanme querido asegurar que es de un hombre arcipreste [...] yo no lo creo" (2012: 208), señalaba, refiriéndose explícitamente tanto a la anonimia como a la difusión manuscrita del texto, citado además como "una respuesta". El texto inédito permite postular la hipótesis de que Quevedo hubiese apuntado hacia esta Respuesta, de la que pudo tener conocimiento: anónima, manuscrita y titulada de modo coincidente. El "hombre arcipreste" citado en los chascarrillos cortesanos bien podría ser el obispo representado por el escudo de armas que precede a la dedicatoria del manuscrito. Ettinghausen (2013: 255) contemplaba ya, con cautela, la posibilidad de que el prólogo de la edición autorizada de Política de Dios no remitiese necesariamente a la impugnación del padre Pineda ni a las ya conocidas, sino a otras perdidas: "resulta difícil determinar si estas menciones tan tempranas por parte de Quevedo se refieren a ellas o a otras que se han perdido". El manuscrito conservado en Pensilvania confirma la existencia de documentos de la controversia hasta ahora desconocidos. Habrá que seguir completando en el futuro, texto a texto, el mapa de una polémica que estamos lejos de conocer en todas sus dimensiones, para trazar relaciones de causalidad entre los escritos más seguras y proponer posibles atribuciones. 
Pronunciarse sobre la presunta influencia de la Respuesta en la reescritura de la obra exige cautela. Las fechas de los últimos preliminares de la edición madrileña de Política de Dios (noviembre de 1626) y la datación exacta de la censura (el 30 de octubre de ese año) sugieren que Quevedo habría tenido escaso tiempo para rehacer su texto a la vista de su contenido, si es que lo conoció, pero ha de aceptarse que no sería imposible: la diatriba pudo circular antes de que existiese o se añadiese su dedicatoria, el único lugar donde consta una fecha. De hecho, la comparación de su texto con los numerosos pasajes modificados en la versión definitiva del tratado evidencia un claro impacto, a diferencia de lo que sucede con la denuncia firmada por Juan de Pineda (Alonso Veloso, 2020b).

En relación con la actualidad política de la obra de Quevedo, se ha sugerido que, escrita en torno a 1621, con Felipe III y el duque de Lerma en el horizonte, hubo de interpretarse en 1626 como "un duro comentario sobre la relación de poder entre Felipe IV y Olivares", "reivindicación, expresada con coraje y osadía", "advertencia implícita, y hasta una amenaza velada, a su valido" (Ettinghausen, 2013: 247-248; y Cacho, 2010: 899). Ettinghausen (2013: 249) se sorprendía de que la censura de Pineda hubiese obviado sus implicaciones políticas, centrando su acusación en "haber pretendido basarse en la autoridad de los Evangelios sin poseer el debido conocimiento teológico", trasfondo religioso común a las impugnaciones de los Sueños y el Buscón, por su "sátira anticlerical y su aparente burla de cosas sagradas". Le extrañaba que la diatriba de Pineda no hubiese puesto reparos "a una obra tan crítica de los peligros atribuibles al poder de los validos y a las debilidades de los monarcas", que su uso de los Evangelios le hubiese dado más notoriedad que su "carga política" (Ettinghausen, 2013: 258).

Ahora comprobamos que la sátira política quevediana no pasó desapercibida, como tampoco el atrevimiento de Quevedo, a juzgar por el contenido de la Respuesta, cuyo texto impugna la "teoría política" de la obra, argumento por argumento, sin por ello descuidar la denuncia del uso irreverente de las Escrituras por parte de un profano. La invectiva que ahora se da a conocer contribuye a despejar, al menos parcialmente, la perplejidad derivada del hecho de que una obra tan osada en lo político hubiese suscitado diatribas de contenido esencialmente religioso. Cierto es que los Peregrinos discursos de Pacheco de Narváez ahondaban en la materia política. Pero las diferencias entre ambos escritos son significativas, por el planteamiento, el contenido y, sobre todo, el contexto y sus posibles efectos: esta última es una respuesta tardía, de 1640, y en cierto modo inútil ya, pues pretende enfrentar a Quevedo con Felipe IV y Olivares (Valladares, 1999: 37), en un momento en que el escritor, encarcelado en San Marcos de León, había caído definitivamente en desgracia. El autor de la impugnación inédita, que escribe como si se sintiese directamente agraviado por las acusaciones de Política de Dios, en el mismo año de su publicación, se 
intuye miembro del círculo próximo al monarca, el de sus consejeros y colaboradores más directos: habría gozado de los conocimientos y la posición necesarios para refutar el tratado también desde la perspectiva del gobierno, en circunstancias en que habría podido causar el mayor daño a Quevedo, cuando aún mantenía vivas todas sus expectativas en el mundo cortesano. Luego de haber desempeñado un papel de relieve en el reinado de Felipe III, como consejero del Duque de Osuna, padeció destierro de Madrid en 1622, pero recuperó el favor real, ya con Felipe IV, lo que le permitió formar parte de su comitiva en el viaje a Andalucía de 1624, y en la visita a Aragón, Cataluña y Valencia de 1626. Su notoriedad cortesana habría incomodado a sus detractores y pronto sería obstaculizada con otro destierro en 1628 , tras intervenir en la controversia sobre el patronato de España. Enfrentado con Olivares (Jauralde, 1999: 541566; y López Ruiz, 2008: 274-286), habría sido alejado de la corte, entre otras razones, porque "en el [...] libro de Gobierno de Cristo solo había querido decir mal del gobierno presente" 21 . En tales vaivenes del favor real (aún volvería a recuperarlo después como secretario del monarca), habría influido su prominencia literaria y política, que despertó tanto interés como ataques constantes contra sus obras de mayor éxito desde múltiples ámbitos ${ }^{22}$.

La Respuesta nos acerca por vez primera a la faceta política inmediata de esta polémica. Nos permite asomarnos a la maraña de consejeros más cercanos, celosos de los favores concedidos por el monarca, y tal vez temerosos de que las ideas de Quevedo encontrasen eco en Felipe IV o llegasen a desvelar las argucias y corruptelas de sus más directos colaboradores. En 1626. En el preciso contexto en que las ediciones de Política de Dios se multiplicaban, y Quevedo intentaba frenar su difusión con una nueva versión corregida y autorizada, pero nunca exenta de intención política. La identificación del autor permitiría entender mejor las razones y las consecuencias que se adivinan entre las líneas del manuscrito anónimo, dirigido, maliciosamente, al confesor real. Pero de su texto se infiere ya, nítido, su objetivo. Desacreditar a Quevedo como posible consejero real, con una mirada de soslayo a su conflictivo pasado político durante el reinado de Felipe III. Impugnar sus "documentos", sus consejos, para salvaguardar la aventajada posición de los más estrechos colaboradores del monarca, su privado y su confesor (Olivares, Sotomayor), que, aunque acomodados en un contexto mejor que el de 1621, constataban la creciente oposición que acechaba ante sus medidas de gobierno. Instar al rey, en fin, para que castigase a Quevedo, un "abatido de la fortuna", un hombre de "otra era" situado en el "bando contrario del privado", relegado del posible favor real, amenazado con la pérdida de la "paz" en que vivía.

\footnotetext{
${ }^{21}$ Así lo argumenta Juan Ruiz Calderón, en carta dirigida a Quevedo y fechada el 1 de agosto de 1628 (Epistolario, 1946: 203), citada por Jauralde (1999: 551).

${ }^{22}$ Crosby (1975: 47) resume estas peripecias, en relación con Política de Dios.
} 
Su progresivo enfrentamiento con Olivares, que será definitivo en la década de los 30, está documentado en fechas posteriores, cuando difunde los memoriales por el patronato de Santiago (1628) y El chitón de las tarabillas $(1630)^{23}$, pero se adivina latente ya en 1626, alentado por algunos consejeros de la corte ocultos entre las sombras privilegiadas de palacio.

\section{BIBLIOGRAFÍA}

Alcalá Galve, Ángel (1986): "Góngora y Juan de Pineda: escaramuzas entre el poeta y el inquisidor", en Homenaje a Pedro Sáinz Rodríguez, 3, Madrid, Fundación Universitaria Española, pp. 1-19.

Alonso Veloso, María José (2015): “Los títulos de Quevedo", La Perinola, 19, pp. 111-148.

Alonso Veloso, María José (2016): "La politique de Dieu: una traducción desconocida de la obra de Quevedo, en un manuscrito del siglo XVII", Dicenda. Cuadernos de Filología Hispánica, 34, pp. 33-67, <https://doi.org/10.5209/dice.53552>.

Alonso Veloso, María José (2017): "Una invectiva inédita contra Gracias y desgracias del ojo del culo de Quevedo", Neophilologus, 101, 4, pp. 523-540, <https://doi.org/10.1007/s11061-017-9532-x>.

Alonso Veloso, María José (2020a): "La respuesta de Quevedo al padre Pineda: una obra posiblemente censurada", Neophilologus, 104, 1, pp. 49-67, <https://doi.org/10.1007/s11061-019-09610-z>.

Alonso Veloso, María José (2020b): "Quevedo censurado: la denuncia que forzó la reescritura de Política de Dios", Bulletin of Spanish Studies, 97, 6, pp. 897-928, <https://doi.org/ 10.1080/14753820.2020.1777721>.

Álvarez y Baena, José Antonio (1790): Hijos de Madrid, ilustres en santidad, dignidades, armas, ciencias y artes, III, Madrid, D. Benito Cano, pp. 378-381.

Antonio, Nicolás (2006): Bibliotheca hispana nova, sive hispanorum scriptorum qui ab anno MD ad MDCLXXXIV floruere notitia [facsímil de la edición de Madrid, Joaquín Ibarra, 1783-1788, 2 vols.], Alacant, Biblioteca Virtual Miguel de Cervantes, $<$ http://www.cervantesvirtual.com/ FichaObra.html?Ref $=21138>$.

Astrana Marín, Luis (1946): Epistolario completo de don Francisco de Quevedo Villegas, Madrid, Instituto Editorial Reus.

Barbazán, Julián (1941): "La Inquisición y los libreros en 1629", Revista de Bibliografía Nacional, 3, pp. 259-264.

Cacho Casal, Rodrigo (2010): "Quevedo contra todos: la segunda parte de la Política de Dios y su contexto", Bulletin of Hispanic Studies, 87, 8, pp. 897-919, <https://doi.org/10.3828/bhs.2010.37>.

Crosby, James O. (1975): The Sources of the Text of Quevedo's Politica de Dios, New York, Modern Language Association of America, 1959 (reimpresión en Millwood, New York, Kraus Reprint Co.).

Del Piero, Raúl A. (1958): "Quevedo y Juan de Pineda", Modern Philology, 56, 2, pp. 82-91, $<$ https://doi.org/10.1086/389252>.

Elliott, John H. (1990): El conde-duque de Olivares: el político en una época de decadencia, trad. Teófilo de Lozoya, rev. Antonio Feros, Barcelona, Crítica.

Ettinghausen, Henry (1969): "Quevedo's Respuesta al P. Pineda and the text of the Política de Dios", Bulletin of Hispanic Studies, 46, pp. 320-330, <https://doi.org/10.3828/bhs.46.4.320>.

Ettinghausen, Henry (2010): "Enemigos e inquisidores: los Sueños de Quevedo ante la crítica de su tiempo", en Eugenia Fosalba y Carlos Vaillo (coords.), Literatura, sociedad y política en el Siglo de Oro, Barcelona, Universitat Autònoma, pp. 297-318.

\footnotetext{
${ }^{23}$ Jauralde (1999: 604) habla de ruptura "casi definitiva" de la colaboración con Olivares en $1630-1631$.
} 
Ettinghausen, Henry (2013): "Quevedo ante la censura: la primera Parte de Política de Dios", en Eugenia Fosalba y María José Vega (coords.), Textos castigados: La censura literaria en el Siglo de Oro, Bern, Peter Lang, pp. 245-262.

Gacto Fernández, Enrique (1991): "Sobre la censura literaria en el s. XVII. Cervantes, Quevedo y la Inquisición", Revista de la Inquisición, 1, pp. 11-61.

Gendreau, Michelle (1977): Héritage et création: Recherches sur l'humanisme de Quevedo, Lille, Champion-Université de Lille III.

Jauralde Pou, Pablo (1999): Francisco de Quevedo (1580-1645), Madrid, Castalia.

López Arandia, María Amparo (2014): "Un paterfamilias en la corte de Felipe IV: fray Antonio de Sotomayor", Historia y Genealogía, 4, pp. 59-74, <https://doi.org/10.21071/hyg.v0i4.345>.

López Ruiz, Antonio (2008): Tras las huellas de Quevedo (1971-2006), Almería, Universidad.

Márquez, Antonio (1980): Literatura e Inquisición en España (1478-1834), Madrid, Taurus.

Morovelli de Puebla, F. (1932): Anotaciones a la Política de Dios, gobierno de Cristo y tiranía de Satanás, en Luis Astrana Marín (ed.), Obras completas de don Francisco de Quevedo Villegas, Madrid, Aguilar, pp. 985-993.

Negredo del Cerro, Fernando (2006): Los predicadores de Felipe IV. Corte, intrigas y religión en la España del Siglo de Oro, Madrid, Actas.

Negredo del Cerro, Fernando (2009): "Gobernar en la sombra. Fray Antonio de Sotomayor confesor de Felipe IV. Apuntes políticos", en María Amparo López Arandia (coord.), Entre el cielo y la tierra. Las elites eclesiásticas en la Europa Moderna, Mágina, Revista Universitaria, 13, pp. 85-102.

Nieremberg, Juan Eusebio (1644): Firmamento religioso de lucidos astros, en algunos claros varones de la Compañía de Jesús, Madrid, María de Quiñones.

Pacheco de Narváez, Luis (1932): Memorial denunciando al tribunal de la Inquisición cuatro libros de D. Francisco de Quevedo, en Luis Astrana Marín (ed.), Francisco de Quevedo, Obras completas. Obras en verso, pp. 1043-1050.

Plata Parga, Fernando (2006): "La polémica en torno a La Perinola de Quevedo con un texto inédito", La Perinola, 10, pp. 245-255.

Plata Parga, Fernando (2019): "La zurriaga de Perinola: edición crítica de un texto inédito contra Quevedo", La Perinola, 23, pp. 85-127

Profeti, María Grazia (1981): "Juan Pérez de Montalbán: 'Índice de los ingenios de Madrid”", Anales del Instituto de Estudios Madrileños, 18, pp. 535-588.

Quevedo, Francisco de (1852-1859): Obras de don Francisco de Quevedo Villegas, ed. Aureliano Fernández-Guerra y Orbe, 2 vol., BAE 23-48, Madrid, Rivadeneyra.

Quevedo, Francisco de (1932): Obras completas Obras en prosa. Obras completas Obras en verso, ed. Luis Astrana Marín, Madrid, Aguilar.

Quevedo, Francisco de (1966): Política de Dios, Govierno de Christo, ed. James O. Crosby, Madrid, Castalia.

Quevedo, Francisco de (2012): Política de Dios, ed. Eva María Díaz Martínez (parte primera) y Rodrigo Cacho Casal (parte segunda), en Alfonso Rey (dir.), Obras completas en prosa, "Tratados políticos", V, Madrid, Castalia, pp. 159-639.

Rey, Alfonso (2014): Lectura del Buscón, Valladolid, Universidad.

Valladares Reguero, Aurelio (1997): "Peregrinos discursos y tardes bien empleadas: una obra desconocida de Pacheco de Narváez contra la Política de Dios de Quevedo", La Perinola, 1, pp. 237-256.

Fecha de recepción: 13 de noviembre de 2018

Fecha de aceptación: 18 de diciembre de 2018 